Special Issue on Federalism and Identity edited by Michael Burgess, Soeren Keil and Sean Mueller

\title{
DEFINING 'EUROPE' AND 'EUROPEANS': Constructing Identity in the Education Policy of the European Union
}

\author{
by Zeynep Arkan
}

Department of International Relations, Hacettepe University, Ankara, Turkey.

Email: zarkan@hacettepe.edu.tr

Abstract: The process of European integration is also a project of identity construction - for 'Europe' to be able to define its role and position in the world and for the 'European peoples' to identify with 'Europe' and its present political and social reality. As the foundations of an embryonic European state were laid down, the need to create a European demos arose more vividly than ever. The 'permissive consensus' was deemed no longer sufficient in achieving the objectives set out for the European Union. The construction and promotion of a new level of belonging, symbolised by the identity of the Union, was seen as a solution to the problems that it has been facing in terms of public support and loyalty. This study, by focusing on the education policy of the European Union, hopes to shed light on one dimension of this process of identity construction. It is argued here that education was seen as a key medium through which a common culture, shared values and aspirations were inculcated among the peoples of 'Europe'. Parallel to this, the policy discourse of the Union in this field contained clues as to how the institutions of the Union viewed its identity and that of its peoples. To explore these and their policy implications, this study applies a discourse analysis framework to analyse representations of the Union's identity in the official texts of the European Union in the sphere of education policy.

Arkan, Z. 2013, Defining 'Europe' and 'Europeans': Constructing Identity in the Education Policy of the European Union, Federal Governance, vol. 10 no. 2, pp. 35-46. 


\section{About Federal Governance}

Federal Governance is an online graduate journal on theory and politics of federalism and multilevel governance. Its mandate is to engage the global federalism community and reach out to outstanding graduate students interested in federalism and multi-level governance. By providing a platform for graduate students to have early success in their careers, Federal Governance seeks to promote and sustain interest in federalism and multi-level governance research among graduate students. Allied with the Forum of Federations and founding partner, Institute of Intergovernmental Relations at Queen's University; Federal Governance aims to contribute to a global dialogue on federalism.

Co Chairs, Advisory Committee:Rupak Chattopadhyay and Christian Leuprecht

Publisher: Forum of Federations

(Rupak Chattopadhyay and Philip Gonzalez)

Managing Editor:

Dominic Heinz

Associate Editors:

Maria Bertel, Carey Doberstein, Sean Müller, Eyene

Okpanachi and Samir Sharma

\section{Terms of Use}

Your use of this Federal Governance article indicates your acceptance of Federal Governance's Terms and Conditions of Use, available at www.federalgovernance.ca/terms. Federal Governance's Terms and Conditions of Use provides that you may use Federal Governance content only for personal, academic and non-commercial use. Each copy of any part of this Federal Governance article must contain the same copyright notice that appears on the screen or printed page of such transmission. 


\section{Introduction}

In addition to equipping younger generations with the skills and knowledge they require in their future, education is also a social programme (Rose 1996: 234). Throughout the history of nation states, education has played an important role in spreading "the image and heritage of the 'nation'" and promoting attachment to this 'imagined community' (Hobsbawm 1992: 91-92). It has been regarded as an important tool with the help of which subjects of the state "were transformed into citizens through the teaching of history, geography, and the language of the nation" (Nuhoğlu Soysal and Schissler 2005: 1).

The states' control over education in general and what is taught in particular have been important aspects in the process of nation-building. By placing the image and historical legacy of the nation in the background of all aspects of political, social and cultural life, states aimed to continuously remind their citizens of their status as parts of a national community and as bearers of a specific national identity.

The way in which the national elite viewed the role of education had parallels at the European Union (EU) level. As the brief overview of the policy area will illustrate, education has been regarded as an important tool with the help of which a European demos could be created, particularly after the 1970s as the process of integration gained speed. In this period, education came to the fore as a response to the perceived deficiencies in the integration process and was seen as a means of bringing 'Europe' "closer to its citizens" (Warne 2000: 255).

This paper explores how the EU represented its identity in its education policy texts and the impact of these representations on the overall policy direction at the European level. To this aim, it first provides a brief overview of this policy area, focusing specifically on the field of general education, i.e. aspects of education related to broader and formal school education. The following part, then, analyses the official texts of the EU in the field of education with a view to uncovering the ways in which the EU institutions 
represented and constructed the EU's identity and discusses how these representations influenced the policy initiatives of the Union.

\section{Education Policy of the EU: A Brief Overview}

Education is a relatively new policy area for the Union on which the Founding Treaties were silent. By not including provisions regarding education policy in the Founding Treaties, Member States aimed to maintain their monopoly on the sphere of education. Initially, the European Community (EC) was only involved in educational matters that were related to its economic mandate in the field of vocational training and mutual recognition of educational and professional qualifications to facilitate freedom of establishment and movement. It was excluded from the field of general education until the 1970s. It was only through the efforts of the European Commission that a Community agenda was first formulated and later, with the help of the European Court of Justice and the European Parliament, the relevant policy tools were created (Christiansen 2001: 98).

Since the early days, the Community initiatives and policy on education have witnessed a constant battle between proponents of active Community involvement under the leadership of the Commission, and those that supported minimal or no Community involvement, led by a number of Member States such as Denmark and the United Kingdom in the Council. It was mainly due to the persistent activism of the Commission that the policy area developed without the existence of sound legal basis and evolved into its current form (Johnson 1999).

Overall, Community initiatives in the sphere of education developed along two lines: the economic dimension of education that focused on employment, growth and labour mobility; and the social and cultural dimension that focused on the integrative and socialising functions of education. In terms of its economic dimension, education was seen as both a tool in facilitating the achievement of key economic goals of the Community, such as freedom of movement and the completion of the internal market programme, and a means through which the Member States could collectively respond to the economic and social problems they were facing. In terms of its social and cultural 
dimension, education was regarded as an appropriate medium for integrating and socialising younger generations in a 'European' environment through exchange and mobility programmes, and, with the 'European content' in education, learning about a shared 'European' history and heritage as well as the current political and social realities of 'Europe'.

\section{Construction of the EU's Identity in Education Policy}

The approach used in this study is based on the assumption that debates within the EU regarding its identity revolve around a number of basic concepts (Hansen 2006; Wæver 2002). These key concepts form the building blocks of policy discussions and shape the way in which the EU defines itself and what it stands for, its role and position in the world, and the direction in which it should be heading.

The first key concept that dominates the debate in the sphere of education is the idea of 'Europe'. This appears in the EU texts in a number of ways; 'the construction of Europe', 'the unification of Europe', 'the European project', and 'the concept of Europe' being the most common ones. In the EU discourse, the term 'Europe' is often used as a seemingly objective geographical reference. Yet, taking into account the existence of multiple 'Europes' that have "different boundaries from the West as well as the East - different organizing principles, and different 'European' values" (Wæver 1993), it can be concluded that this conception of 'Europe' is neither neutral nor purely geographical. While the vague and symbolic nature of the term 'Europe' is not particular to the EU discourse as many works on the history of the idea of Europe and European unity illustrate, in the case of the EU, how 'Europe' is conceptualised affects how the Union views itself and its peoples, and how it formulates its policies and acts.

The second key concept is that of 'Europeans'. This concept appears in the texts in a number of ways: 'the peoples of Europe', 'European people', 'citizens of Europe' or simply 'Europeans'. These usages of the term are inherently linked to the concept of 'Europe' and are analysed in this paper as such in relation to the way the nations within the EU are represented taking into account alternative ways of conceptualising and representing them. 
The Initial Steps of the EC in the Sphere of General Education: 1963-1984

The core concept that dominated the discussions on education in this period was the idea of 'Europe' not only as a geographical entity, but also as a historical and cultural construct with a legacy shared by all 'European' states - a term that usually differentiated the members of the Community from the rest. In accordance with this, 'Europe' was represented as a region that not only had a common civilisation, culture and heritage, entailing a special responsibility towards the rest of the world, but also as containing the seeds of unity and a collective identity. This collective identity was to be defined along the lines of "the common heritage, interests and special obligations" of the Member States who "have decided that unity is a basic European necessity to ensure the survival of the civilisation which they have in common" (Declaration on European Identity 1973). The legacy of this community, which was seen as interrupted in certain periods of 'European' history owing to the egoistic pursuance of national interests (such as during the Second World War), bestowed on the Community the special task of pursuing greater integration in order not to return to a conflictual past. Parallel to this, the Community was seen as a unique experiment undertaken by the leaders of the six founding Member States to build a better future for the 'citizens of Europe' who shared a "sense of belonging to one and the same community with a common heritage from the past and a common destiny for the present and the future" (Commission of the European Communities 1977: 8).

This representation of 'Europe' and its identity was particularly dominant in early documents of the EC, especially those originating from the Commission. The Janne Report, for example, argued that 'Europeans' feeling of political, social and cultural belonging can no longer be exclusively national if a part of the attributes of the nationstate has been tested in the Community" (Commission of the European Communities 1973: 51). Parallel to this, the report advised Member States to undertake a very ambitious set of actions which included the 'correction' of history textbooks "with a view to expunging or amending nationalistic, biased passages", and the teaching of 'European' civics (Commission of the European Communities 1973: 52). 
The analysis of the documents and decisions adopted in this period by the Commission, and to a certain extent the Parliament, illustrate that these institutions recognised the importance of education as a tool in facilitating awareness and solidarity among the citizens of 'Europe' at the very early stages of the process of integration. Through references to a common 'European' identity, heritage, history, culture, and set of values, they aimed to bring together the citizens of Member States in a transnational jigsaw, in which national units formed the pieces of a harmonious whole. The initiatives taken up by the Community thus reflected an eagerness on the part of the EC elite to socialise younger Europeans into their common 'European' identity at an early age as part of "the endeavour to create a "European cultural area" to correspond to the "European economic space"' (Rosenthal 1991: 273). To this aim, a key focus of the early initiatives of the Community became the promotion of foreign language teaching and mobility to promote greater mutual understanding between the citizens of Member States, and to remove the barriers between them. On an abstract level, the Community discourse, particularly that of the Commission, created an ideal 'European citizen' who was mobile, multilingual, and was aware of his/her common 'European' heritage and the advantages of belonging in the Community. These citizens, by becoming true 'Europeans', succeeded in freeing themselves from national biases and prejudices, identified "their common links from amongst the wealth of their cultural diversity, links which, despite the adversities and enmities of their history, make them joint inheritors" (Commission of the European Communities 1977: 15) and embraced their 'European identity'.

This ambitious project of creating ideal 'European citizens', however, faced one major obstacle: Member State governments as represented in the Council of Ministers. Many of the proposals and reports sent to the Council in this period were either ignored or watered down, which illustrated the uneasiness of the Member States about EC involvement in the sphere of education. The Council, instead, highlighted the theme of respect for the cultural and linguistic diversity of the Member States, and chose to focus on the activities that it deemed less threatening and mostly related to the economic dimension of education. 
The Second Phase of EC Activity in the Field of Education: 1985-1991

In contrast to the first phase of activity during which the building blocks of education policy were laid down, the second phase witnessed a consolidation of the efforts of the Community and the materialisation of a framework for action. The majority of the texts in this period were thus more technical and specific. Nevertheless, a number of texts that aimed to provide a general direction and long-term perspective for the Community in its educational activities still echoed the themes of continuity and commonalities introduced previously.

As in the first period, the term 'Europe' was mainly used to refer to the space occupied by the Communities. The references to 'European' historical and cultural commonalities referred to in this period were, though not as frequent, still present: "the Community citizen sees as being intimately linked to his feelings of identity and of belonging to the European Community" that "establishes a European area based on common cultural roots as well as social and economic realities" (Commission of the European Communities 1989: 7). These called for a set of activities that "strengthen in young people a sense of European identity and make clear to them the value of European civilization and of the foundations on which the European peoples intend to base their development today" (Council of Ministers of the European Communities 1988: 5).

In this period, the significance of education for the Community had two interrelated dimensions: the economic and the social. In terms of the economic dimension, it was argued that the new realities of 'Europe', particularly the aim of completing the internal market, provided a new context for educational activities in a 'Europe without frontiers'. The present and future workforce of the Community, it was argued, had to match the requirements and "needs of the economy and society in Europe" (Commission of the European Communities 1989: 2). For 'Europe' to respond to these changes and to make the best of its human capital, national authorities, in cooperation with the Community, needed to plan the skills required for the 'Europe' of tomorrow and to improve their existing structures and quality of education through a long-term perspective.

The social dimension of the educational activities of the EC, on the other hand, mainly involved providing new momentum to the European dimension of education which was 
seen as a key aim for the future of 'Europeans'. The renewed efforts of the Community focused particularly on mobility in education and the flagship programmes of the Community - Erasmus, Lingua and Comett - as well as the teaching of foreign languages. These flagship programmes aimed to provide citizens with the opportunity to take advantage of the European market, to prepare for active citizenship at the Community level, and also to enhance their mutual understanding of cultural differences in and the inherent unity of 'Europe'.

Education Policy in the EU: 1992-1999

The following period saw a shift of focus and tone in the EU's discourse. While references to 'Europe' and 'Europeans' were frequent, these references were quite subdued, particularly in relation to the shared cultural elements between the Member States. In this period, the provisions regarding education in the Maastricht Treaty were important in the sense that, for the first time, educational activities of the EU were provided with a firm legal basis. They, however, limited the role of the Union in this field to supporting and supplementing the actions of the Member States and encouraging cooperation between them. This de facto limitation of the competences of the EU became a recurring theme in the texts, almost all of which emphasised the 'added value' of Community initiatives.

The reluctance of Member States in granting the Union more powers in the field of education, coupled with economic concerns, soon led to changes in the existing discourse and introduced a particular focus on the economic and civic dimensions of education in the 1990s. The EU discourse now emphasised the role that education could play in promoting growth, employment and competitiveness, and enhancing the international competitiveness of the Union. While EU documents still contained references to a European dimension in education through experiences of mobility and exchange programmes, references related to the 'European content' of education were virtually non-existent. 
In this period, identity references in the discourse on education focused also on promoting the recently constitutionalised EU citizenship. In relation to the linkages between education and this new level of citizenship, the Commission argued that (Commission of the European Communities 1993: 5),

(e)ducation systems are not limited to ensuring the continuation of their own cultures; they must also educate young people for democracy, for the fight against inequality, to be tolerant and to respect diversity. They should also educate for citizenship...

This emphasis on EU citizenship had a substantial impact on identity discussions as it shifted the approach to identity from a historical one founded upon assumptions of a shared civilisation, heritage and culture, to a civic perspective that emphasised the values, norms and principles that formed the basis of the Union. Parallel to this, this new approach also altered the temporal dimension of identity by focusing on the present and the future of 'Europe' instead of its past. This change rendered the EU's identity more open and welcoming towards others and, parallel to this, required little adaptation as the Union made room to accommodate new Member States in the following decade. The discourse on education thus became more inclusive in its tone, and focused more on the cultural and linguistic wealth of 'Europe' instead of the unifying cultural and historical aspects of its civilisation.

\section{Education Policy and the EU's Economic and Social Strategy: 2000-present}

The period that followed witnessed the consolidation of the initiatives and programmes of the EU and the intensification of efforts at both the Union and Member State levels. In the 2000s, the contribution that the Union can make in the field of education was discussed in great detail in relation to the economic and civic dimensions of education. In fact, these two dimensions of education formed the main topics in the EU discourse on education, the former mostly discussed under the headings of investment in the human resources of 'Europe' and enhancing the competitiveness of the EU in the international arena, while the latter was discussed in relation to greater social cohesion, equal opportunities, and preventing social exclusion, racism and xenophobia.

In terms of the economic dimension of education, this period witnessed a new trend in the educational activities of the EU following the adoption of the Lisbon Strategy. This 
new economic, social and environmental strategy of the Union upgraded education policy and assigned it a key role in achieving the ambitious goal of making the EU the most competitive and knowledge-based economy. Education was given an important role in achieving the targets set particularly in relation to the investment to be made in 'the peoples of Europe', which required adapting the education and training systems of 'Europe'. In line with the growing interest in and importance attached to education, initiatives at the EU level, which were restructured and reformed to reflect the changing needs of 'Europe', started receiving more support and funding.

The EU's education discourse also reflected a growing concern with the socialising effects of education programmes as well as the civic dimension of education related to promoting EU citizenship: "Education and training have a crucial role to play in meeting the many socio-economic, demographic, environmental and technological challenges facing Europe and its citizens today and in the years ahead." (Council of Ministers of the European Communities 2009: 2). In terms of the EU's identity, while the latest enlargements of the Union provided it with the possibility of becoming a stronger and more visible international actor, they rendered the option of emphasizing the 'unifying' elements of 'Europe's common history, civilisation and heritage virtually impossible. In line with this, identity discussions in this period focused more on the civic dimension of identity mostly related to EU citizenship and representations of EU identity reflected a strong emphasis on the values, norms and principles that brought the peoples and states of 'Europe' together.

\section{Conclusion}

The EU's discourse on education reflected a changing conception of EU identity over the years. The early discourse on education policy, particularly originating from the Commission, contained references that connected 'Europe' and 'Europeans' through a set of commonalities. These commonalities included those related to 'Europe's past as in the case of a common civilisation, history, cultural, and linguistic heritage; its present, in terms of the values, principles and objectives of the Union; and its future, in the form of a common destiny. Various representations of these commonalities illustrated the foundations on which the current reality of 'Europe' was built and underlined the continuous and almost uninterrupted existence of this 'Europe' throughout history. As the 
EU evolved, these representations were toned down to reflect a growing concern with the economic and civic dimension of education, and the normative foundations of the Union. In this period, the identity of the EU was based more on the shared present and future prospects of the states and peoples of 'Europe', and their common concerns.

The key debates in education policy rested mainly on the question of competences and to what extent the EU could intervene in the sphere of education. Despite its limitations in terms of its powers, by attempting to create a European dimension to education through education programmes and exchanges of information and experiences, the Union aimed to offer an added value in the sphere of education and to increase the overall quality of education as a response to the changing economic and social conditions. In this respect, the education policy of the EU not only represented a suitable forum for responding to the common problems and concerns of the Member States, it also served as an important medium through which the younger generations could advance themselves in a multicultural and multilingual 'European' environment to compete in the global labour market.

Consequently, the main problem that the EU faced in constructing and reproducing its identity through education policy was that it was trying to utilise the same media and means that Member States employed in instilling a common identity and sense of solidarity among their citizens, though it did not enjoy the powers that state governments had. While a number of initiatives that the EU undertook in the field of education contributed to the process of interaction and socialisation in a 'European' space, such as its rather successful educational programmes, the outcome that the EU desired in terms of creating an alternative identity and a new level of belonging appears far from achieved at this stage.

\section{References}

[1] Christiansen, T. 2001, "The European Commission: Administration in Turbulent Times" in European Union: Power and Policy-Making, ed. J. Richardson, Routledge, London, pp. 95-114.

[2] Commission of the European Communities 1993, Green Paper on the European Dimension of Education, COM (93) 457 final, Brussels. 
[3] Commission of the European Communities 1989, Education and Training in the European Community: Guidelines for the Medium Term: 1989-1992, COM (89) 236, Brussels.

[4] Commission of the European Communities 1977, Report on the Establishment of a European Foundation, Bulletin of the European Communities, Supplement 5, Luxembourg.

[5] Commission of the European Communities 1973, For a Community policy in education, Bulletin of the European Communities, Supplement 10, Luxembourg.

[6] Council of Ministers of the European Communities 2009, Council conclusions of 12 May 2009 on a strategic framework for European cooperation in education and training ("ET 2020"), Brussels.

[7] Council of Ministers of the European Communities 1988, Resolution of the Council and the Ministers of Education meeting within the Council on the European dimension in education of 24 May 1988, Brussels.

[8] Declaration on European Identity 1973, Bulletin of the European Communities, No. 12, Luxembourg.

[9] Hansen, L. 2006, Security as Practice: Discourse Analysis and the Bosnian War, Routledge, Abingdon.

[10] Hobsbawm, E.J. 1992, Nations and Nationalism since 1780: Programme, Myth, Reality, Cambridge University Press, Cambridge.

[11] Johnson, N. 1999, "From Vocational Training to Education: The Development of a No-frontiers Education Policy for Europe?", Education and the Law, vol. 11, no. 3, pp. 199-213.

[12] Rose, R. 1996, What is Europe? A Dynamic Perspective, Harper Collins, New York.

[13] Rosenthal, G. 1991, "Education and Training Policy" in The State of the European Community: Policies, Institutions and Debates in the Transition Years, eds. L. Hurwitz \& C. Lequesne, Lynne Rienner, Boulder, CO, pp. 273-283.

a. Nuhoğlu Soysal Y. \& Schissler H. 2005, "Introduction: Teaching beyond the National Narrative" in The Nation, Europe, and the World, eds. H. Schissler and Y. Nuhoğlu Soysal, Berghahn Books, New York and Oxford, pp. 1-9.

b. Wæver, O. 2002, "Identity, Communities and Foreign Policy: Discourse Analysis as Foreign Policy Theory" in European Integration and National Identity: The Challenge of the Nordic States, eds. L. Hansen \& O. Wæver, Routledge, London, pp. 20-49. 
[14] Wæver, O. 1993, "Essay 3 - Europe since 1945: Crisis to Renewal" in The History of the Idea of Europe, eds. K. Wilson \& J. van der Dussen, Open University Press, Milton Keynes, pp. 116-169.

[15] Warne, C. 2000, "Transnational Affinities in the European Context: the Case of Contemporary French Youth Cultures" in Why Europe? Problems of Culture and Identity, Volume 2: Media, Film, Gender, Youth and Education, eds. J. Andrew, M. Crook, D. Holmes \& E. Kolinsky, Macmillan, London, pp. 255-272. 